\title{
Practical results of the improvement of clay cover soils
}

\author{
A. P. HIDDING and G. P. WIND \\ Institute for Land- and Water-management Research, Wageningen, Netherlands
}

\section{Summary}

In this paper the authors have tested, in pot experiments and on a number of trial fields, the theory described in a previous paper (WIND and HIDDING, 1961). From the experiments it can be concluded that the results of the improvement of clay cover soils can be calculated from the gain in available water.

\section{Introduction}

One of the means to improve clay cover soils is the mixing of sand from the subsoil with the clayey top layer. The structural improvement allows the roots to grow deeper, making it possible to the crop to draw more moisture from the profile.

The total amount of moisture that by capillary rise is available to the plant in a specific profile at a specific moment can be calculated with the aid of the theory of capillary conductivity (WIND and HidDING, 1961).

DE WIT (1958) came to the conclusion that a rectilinear relation exists between transpiration and yield. A combination of both theories would make it possible to calculate the productivity of a soil before and after improvement.

In this paper an analysis will be made of pot-culture and field experiments, executed to test the validity of the theories and their combination, and to evaluate the practical significance of being able to determine theoretically the effect of an improvement of clay cover soils.

\section{Procedure}

\subsection{Pot experiments}

Pots with a diameter of $50 \mathrm{~cm}$ and a depth of respectively 70 and $100 \mathrm{~cm}$ were filled with artificial profiles of clay cover soils.

The subsoil in every pot consisted of sand, compacted to such an extent that no root growth in it could occur, the upper boundary lying at depths of respectively 20 , 35,50 and $65 \mathrm{~cm}$ below surface. The topsoil consisted of clay mixed with sand from the subsoil. Mixtures were made with a clay percentage by volume of $70,55,40$ and $25 \%$. Two pots were taken with every possible combination of clay content and depth of the subsoil.

The pots could drain freely and the amount of drain water was measured. The moisture content in the profile was measured by means of nylon units.

Received for publication 5th May, 1963. 
Total evapotranspiration was calculated as the sum of rainfall minus drainage plus the difference between the moisture content in the profile at the beginning and at the end of the growing season. For the statistical calculations the means of the duplicates were used.

\subsection{Fie $1 \mathrm{~d}$ experiments}

When improving clay cover soils in practice some conditions must be fullfilled. The top layer should always contain at least $10 \%$ of clay; if it contains less, the hazards of wind erosion are too great. This implicates that the profile should not be turned upside down completely.

To make the total amount of water in the profile available, a good root distribution is necessary. The greatest number of roots will be found at the boundary of clay and sand. The clay layer must therefore be broken up into particles as small as possible. Another argument for thoroughly breaking and mixing is, that the clay particles must act as stabilizers of the new soil structure. The sand will again turn into a compact mass if the mixing is not thorough enough.

In most cases the mixing on the experimental field was done by deep ploughing. During the last two years, however, better mixing at lower costs was achieved by using a 'mixing rooter' (FIG. 1).

On a number of fields, normal arable land, in the South-West of the Netherlands, a half of each field was mixed by ploughing while the other half was left undisturbed. Ground-water depths were measured in tubes and yields were determined.

The total yield was found as the total amount of dry matter harvested, and the dry weight of stubble and roots. The latter was taken from figures found in literature.

From the measured ground-water depths the total available moisture in the soil was calculated according to the theory described by WIND and HidDING (1961). Together with rainfall, the available moisture gave the actual transpiration.

\section{The rectilinear relation between transpiration and dry-matter production}

According to DE WIT (1958) there is a rectilinear relation between transpiration and dry-matter production. The regression coefficient in this relation varies with the kind of crop. It is possible that other factors, as for instance fertility, can affect this regression coefficient too. When mixing topsoil and subsoil, a change in fertility might be expected. A pot-culture experiment was therefore made to test the rectilinear relation in a case like this.

\subsection{0 , crop spring barley}

The following variables were included in the calculations of which the results are given in TABLE 1:

$\mathrm{D}$ : depth of topsoil in $\mathrm{cm}$,

C: clay content of topsoil,

$\mathrm{E}$ : evapotranspiration in $\mathrm{mm}$,

$\mathrm{Y}$ : yield, as total amount of dry matter in $\mathrm{kg} / \mathrm{ha}$,

$S$ : number of productive stalks.

The original values of $E, Y$ and $S$ can be split up into their expectation values and rest values. The last ones can be considered to be accidental differences between the expected and the measured values. 


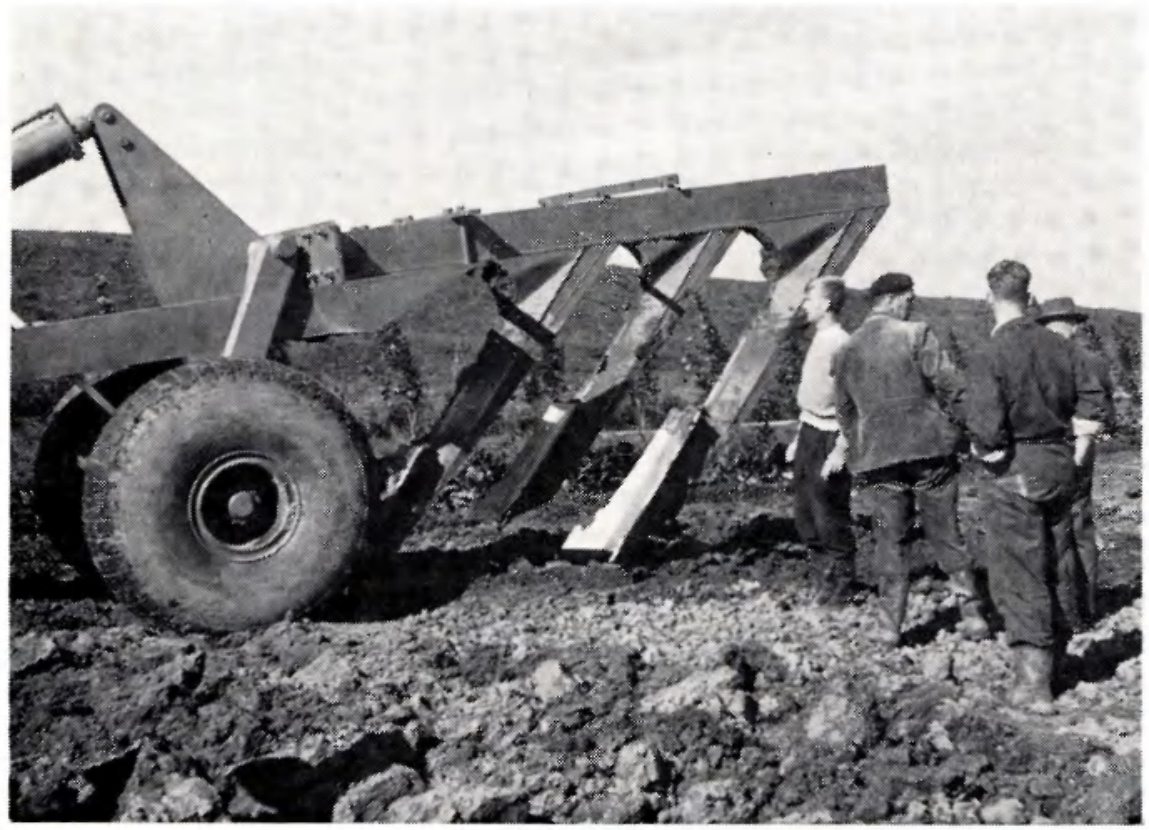

FIG. 1. Mixing rooter 
TABLE 1. Evapotranspiration (E), yield (Y) and number of productive stalks (S), as influenced by clay content (C) and depth (D) of the top layer for spring barley (1960) and oats (1961) in pot experiments

\begin{tabular}{|c|c|c|c|c|c|c|c|c|c|c|}
\hline \multirow{3}{*}{\multicolumn{2}{|c|}{$\mathrm{C}$ in $\%$}} & & \multicolumn{8}{|c|}{$D$ in $\mathrm{cm}$} \\
\hline & & & \multicolumn{2}{|c|}{20} & \multicolumn{2}{|c|}{35} & \multicolumn{2}{|c|}{50} & \multicolumn{2}{|c|}{65} \\
\hline & & & 1960 & 1961 & 1960 & 1961 & 1960 & 1961 & 1960 & 1961 \\
\hline 100 & $\ldots$ & $\begin{array}{l}\mathbf{E} \\
\mathbf{Y} \\
\mathbf{S}\end{array}$ & - & $\begin{array}{r}199 \\
192 \\
49\end{array}$ & - & $\begin{array}{r}220 \\
221 \\
49\end{array}$ & - & $\begin{array}{r}233 \\
195 \\
49\end{array}$ & - & $\begin{array}{r}252 \\
224 \\
63\end{array}$ \\
\hline 70 & $\ldots \ldots$ & $\begin{array}{l}\mathbf{E} \\
\mathbf{Y} \\
\mathbf{S}\end{array}$ & $\begin{array}{l}253 \\
221 \\
154\end{array}$ & $\begin{array}{r}197 \\
173 \\
42\end{array}$ & $\begin{array}{l}237 \\
206 \\
136\end{array}$ & $\begin{array}{r}203 \\
183 \\
43\end{array}$ & $\begin{array}{l}288 \\
202 \\
124\end{array}$ & $\begin{array}{r}206 \\
224 \\
47\end{array}$ & $\begin{array}{l}348 \\
276 \\
177\end{array}$ & $\begin{array}{r}230 \\
232 \\
48\end{array}$ \\
\hline 55 & . . & $\begin{array}{l}\mathbf{E} \\
\mathbf{Y} \\
\mathbf{S}\end{array}$ & $\begin{array}{l}233 \\
170 \\
124\end{array}$ & $\begin{array}{r}180 \\
176 \\
48\end{array}$ & $\begin{array}{l}169 \\
193 \\
133\end{array}$ & $\begin{array}{r}195 \\
176 \\
47\end{array}$ & $\begin{array}{l}294 \\
209 \\
138\end{array}$ & $\begin{array}{r}226 \\
211 \\
46\end{array}$ & $\begin{array}{l}334 \\
310 \\
189\end{array}$ & $\begin{array}{r}262 \\
249 \\
54\end{array}$ \\
\hline 40 & $\ldots \ldots$ & $\begin{array}{l}\mathbf{E} \\
\mathbf{Y} \\
\mathbf{S}\end{array}$ & $\begin{array}{l}238 \\
142 \\
110\end{array}$ & $\begin{array}{r}200 \\
152 \\
45\end{array}$ & $\begin{array}{l}245 \\
267 \\
112\end{array}$ & $\begin{array}{r}205 \\
198 \\
48\end{array}$ & $\begin{array}{l}251 \\
173 \\
130\end{array}$ & $\begin{array}{r}198 \\
183 \\
45\end{array}$ & $\begin{array}{l}274 \\
261 \\
166\end{array}$ & $\begin{array}{r}205 \\
213 \\
51\end{array}$ \\
\hline 25 & $\ldots \ldots$ & $\begin{array}{l}\mathbf{E} \\
\mathbf{Y} \\
\mathbf{S}\end{array}$ & $\begin{array}{l}240 \\
140 \\
116\end{array}$ & $\begin{array}{r}181 \\
144 \\
47\end{array}$ & $\begin{array}{l}231 \\
167 \\
126\end{array}$ & $\begin{array}{r}179 \\
167 \\
47\end{array}$ & $\begin{array}{l}248 \\
214 \\
144\end{array}$ & $\begin{array}{r}206 \\
187 \\
44\end{array}$ & $\begin{array}{l}256 \\
202 \\
146\end{array}$ & $\begin{array}{r}217 \\
180 \\
49\end{array}$ \\
\hline
\end{tabular}

The co-variance analysis shows, that there is no significant regression of $\mathrm{E}$ on $\mathrm{S}$. So the differences in numbers of productive stalks are not caused by differences in transpiration. Higher transpiration causes higher yields, by means of bigger grains, bigger stalks, more grains or more stalks. As the influence of the number of stalks on the yield can only be shown to be significant in the rest values, there is no need to correct the expectation values of the yield for number of stalks.

The relation between $\mathrm{E}$ and $\mathrm{Y}$ can be calculated from the expectation values. This relation is given by

$$
\mathrm{Y}=66,2 \mathrm{E}-7380 \text { (FIG. 2). }
$$

From this formula follows that $110 \mathrm{~mm}$ is already evaporated when production is zero. One of the causes is that roots and stubble were not harvested. According to literature data (KöHNLEIN, 1954; KöNEKAMP, 1953) this mass will have been in the neighbourhood of $2000 \mathrm{~kg} / \mathrm{ha}$ dry matter (see TABLE 3). This means that approximately $35 \mathrm{~mm}$ water was needed to produce roots and stubble. An other factor is the evaporation from the bare soil. It is assumed that the rainfall under this circumstance is totally lost in so far it does not exceed maximal evaporation (DE WIT, 1958). In our case approximately $20 \mathrm{~mm}$ was lost by direct evaporation. The remaining amount must be attributed to runoff from the pots in July, when very heavy showers occurred.

We assumed the mass of roots and stubble to be constant. Although water deficiency in the later part of the growing period for cereals is the only factor that influences total yield, it is not likely this will influence the mass of stubble and roots to any appreciable extent. It is on the other hand reasonable to expect that rooting depth and root mass are highly correlated. In an other pot experiment we found nothing of this kind, however. In that experiment the rooting depth in 
a sandy soil was also regulated by compacting the sandy subsoil. The topsoil consisted of sand with the same total mass of organic matter, independent of the thickness of the toplayer.

Under corn we found the following root weights :

$$
\begin{array}{llrrrr}
\text { Rooting depth (cm) : } & 20 & 40 & 60 & 80 \\
\text { Dry matter }\left(\mathrm{g} / \mathrm{m}^{2}\right) & : & 260 & 240 & 260 & 260
\end{array}
$$

Data from SCHUURMAN (1955) confirm this result. The explanation seems to be that in shallow layers an excssive radial growth of the roots occurs on the boundary with the not penetrated subsoil.

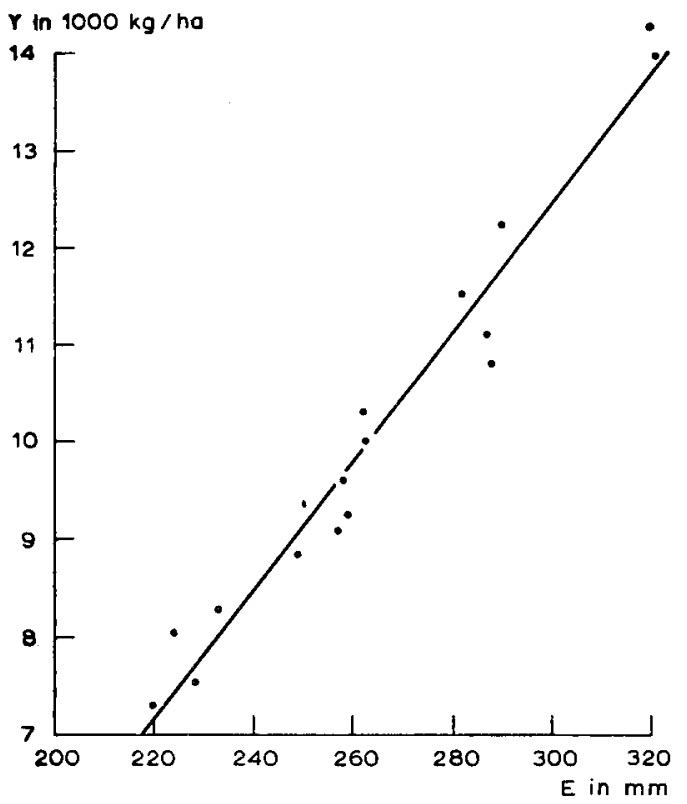

FIG. 2

Relation between evapotranspiration (E) and yield (Y) according the expectation values for spring barley in 1960 (pot experiments)

\subsection{1 , crop oats}

In this year pots with top layers containing $100 \%$ clay were included in the experiment. The same trend as in 1960 was found (see TABLE 1). There was a rectilinear relation between yield and evapotranspiration, that can be written as:

$$
\mathrm{Y}=59,0 \mathrm{E}-2700 \text { (FIG. 3). }
$$

In this experiment runoff was excluded by covering the pots with a plastic shelter during heavy rainfall. In the calculations this amount of rain that did not reach the crop was, of course, subtracted from the used precipitation data. Direct evaporation is estimated to have been approximately $15 \mathrm{~mm}$. When accounting for all the moisture this would mean that root and stubble together equalled $1800 \mathrm{~kg}$ dry matter and this is in good accordance with literature data.

From the results of these experiments we may conclude that mixing subsoil and clay cover does not change fertility substantially. So we may assume that the linear relation between transpiration and yield stays valid when comparing treated and untreated soils. 


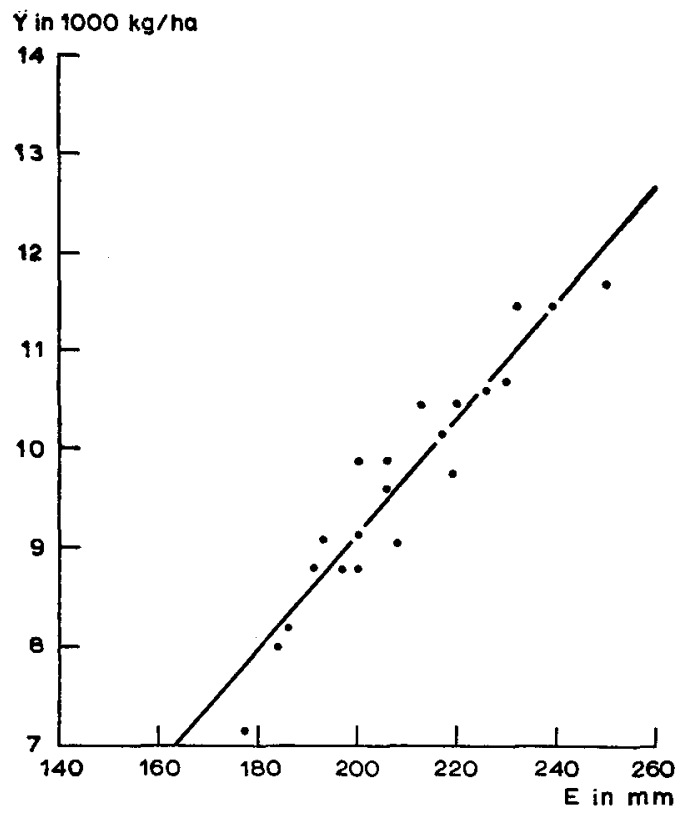

FIG. 3

Relation between evapotranspiration (E) and yield (Y) according the expectation values for oats in 1961 (pot experiments)

\section{Calculation of the amount of moisture available from the soil}

To test the theory of WIND and HIDDING (1961), the potential profiles measured with nylon units have been compared with the profiles calculated with their theory. Because of the low moisture content of the sandy subsoil, testing by means of moisture samples was not possible.

When calculating a potential profile one has to know the flow velocity and for one place in the profile (for instance the bottom of the root layer), the actual suction. The best moment to calculate and to measure the potential profile is at the end of a long dry period, when flow velocities will be about $0,1 \mathrm{~mm}$ a day of less.

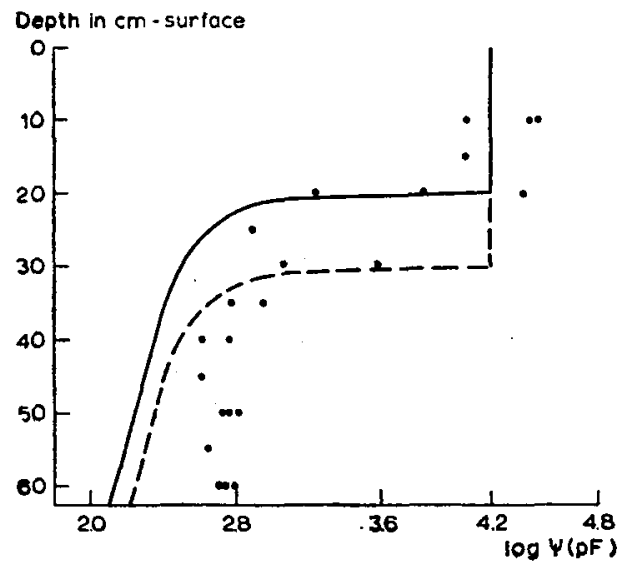

Fig. 4

The measured moisture profile in pots with a clay cover of $20 \mathrm{~cm}$ at the end of the growing season and the theoretical profiles for root depths of resp. 20 (solid line) and $30 \mathrm{~cm}$ (dashed line) at a flow velocity of $0,5 \mathrm{~mm} /$ day 
At the end of the growing season the pF-values given in FIG. 4 were found in four pots with a clay cover of $20 \mathrm{~cm}$. An abrupt fall occurs in the layer of $20-30 \mathrm{~cm}$ below surface. The two lines in this graph are the theoretical profiles at a flow velocity of $0,5 \mathrm{~mm}$ a day. There is some incertainty on the exact place of the nylon units and the root boundary will not be at exactly the same depth as the clay boundary. That the measured profile becomes vertical at $\mathrm{pF} 2,7$, is caused by the free drainage of the pots.

In a trial field we found by sampling after a dry period with a duration of about four weeks in 1959, the potential profiles given in FIG. 5. Here also the measured points agree to a great extent with the theoretical profiles, calculated for a flow velocity of $0,5 \mathrm{~mm}$ a day.

From this we concluded that the amount of moisture that becomes available by capillary rise can be calculated with some accuracy by means of our previously published theory.

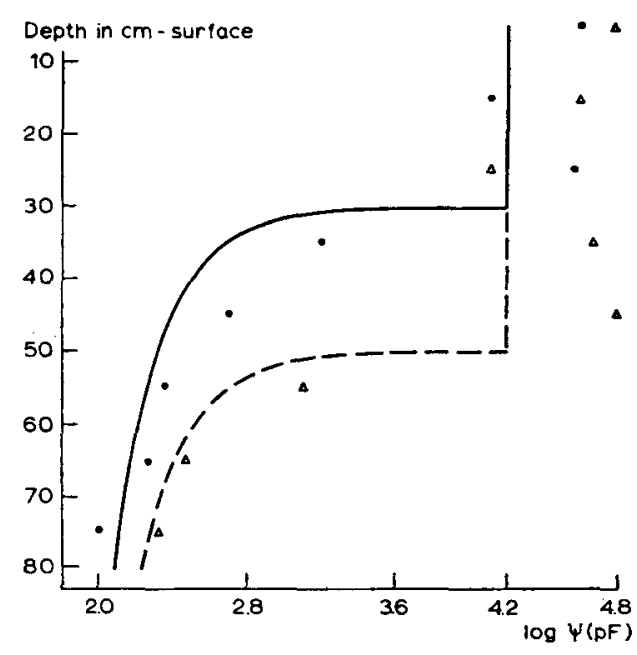

FIG. 5

The measured moisture profiles in a field with a clay cover of $30 \mathrm{~cm}$ at the end of a four weeks dry period; root depth $30($.$) and 50(\triangle) \mathrm{cm}$. Drawn are the theoretical profiles for root depths of 30 (solid line) and 50 (dashed line) $\mathrm{cm}$ at a flow velocity of $0,5 \mathrm{~mm} / \mathrm{day}$

\section{Calculation of the actual transpiration}

To calculate the total transpiration, the following things have to be known :

a. The rainfall used. Although precipitation on bare soil will cause evaporation, it does not contribute to the production of organic matter. During the period that transpiration is less than precipitation, only that amount of rain is effective that equals the transpiration of the crop. Crop transpiration was estimated with the aid of Penman's formula. The meteorological data were derived from the weather station at Vlissingen, situated in the neighbourhood of the experiment fields.

To obtain the transpiration by the crop the value $\mathrm{E}_{0}$ will have to be multiplied by a reduction factor. In our case the reduction factors given in TABLE 2 were used.

b. The moisture content of the root zone. This amount of available water was determined by means of the $\mathrm{pF}$ at every depth in the profile, at that moment in spring when transpiration equalled precipitation. The difference in water content at the pFvalue found in this way and at $\mathrm{pF} 4,2$ was derived from the $\mathrm{pF}$-curve. 
PRACTICAL RESULTS OF THE IMPROVEMENT OF CLAY COVER SOILS

TABLE 2. Reduction factors used to convert evaporation into transpiration

\begin{tabular}{|c|c|c|c|c|c|c|}
\hline \multirow[t]{2}{*}{ Month } & \multicolumn{6}{|c|}{ Crop } \\
\hline & spring wheat & winter wheat & beets & peas & & potatoes \\
\hline$\ldots \ldots \ldots \ldots$ & 0,5 & 0,6 & 一 & 一 & & 一 \\
\hline April $\ldots \ldots \ldots \ldots$ & 0,7 & 0,8 & 0,3 & 0,4 & & 0,3 \\
\hline May $\ldots \ldots \ldots \ldots$ & 0,8 & 0,8 & 0,5 & 0,7 & & 0,5 \\
\hline June $\ldots \ldots \ldots \ldots$ & 1,0 & 1,0 & 0,8 & 1,0 & & 0,8 \\
\hline July $\ldots \ldots \ldots \ldots$ & 0,7 & 0,7 & 1,0 & 0,8 & & 1,0 \\
\hline August $\ldots \ldots \ldots \ldots$ & 0,5 & 0,5 & 1,0 & 0,5 & & 0,8 \\
\hline September ....... & - & - & 0,6 & - & r & 0,5 \\
\hline
\end{tabular}

c. The capillary supply. WIND and HidDiNg (1961) calculated the maximum amount of moisture that could be extracted from the sub-root zone. We then took it that a capillary flow existed during 100 days, beginning with a moisture potential of $10 \mathrm{~atm}$. in the root zone and with field capacity in the sub-root zone. Because the subsoil dries out during this extraction, the potential gradient as well as the capillary conductivity strongly decreases. The flow velocity decreases therefore at the end of the growing season to such low values as $0,2 \mathrm{~mm}$ a day. In this investigation, however, we must calculate the actual amount of moisture extracted from the subroot zone. The difficulty is, that one cannot exactly determine when and with what amount, gradient flow starts. It was, somewhat arbitrarily, assumed that the flow begins when half of the available moisture in the root zone has been used. The mistake in the total amount of flow from the subsoil will only be small.

\section{Field experiments and their results}

Field experiments were carried out in order to prove that the ratio $Q_{y}$ of the total dry-matter production on an improved and on an original profile equals $Q_{m}$, the latter being the ratio of the actual amount of water transpired on the improved and on the original profile. This could be expected since yield has a linear relationship with the amount of actual transpiration - which can be calculated - and it appeared in pot experiments that this relationship stays valid for original and improved profiles. Underneath an example is given of the way $Q_{y}$ and $Q_{m}$ were calculated:

Experiment field : Dees, Koninginnepolder

Depth original clay cover : $30 \mathrm{~cm}$

Crop : spring barley

Harvesting date : July 18 th, 1960

Depth of gronud-water table in $\mathrm{cm}$ below surface :

28/III : $155 ; 28 /$ IV : $180 ; 14 / \mathrm{V}: 200 ; 30 / \mathrm{V}: 200$.

Evaporation according to Penman $\left(E_{o}\right)$; evapotranspiration $\left(E_{p}\right)$ and effective rainfall $\left(R_{e}\right)$ :

\begin{tabular}{lcccc}
\hline Month & & $\mathrm{E}_{\mathrm{o}}(\mathrm{mm})$ & $\mathrm{E}_{\mathrm{p}}(\mathbf{m m})$ & $\mathbf{R}_{\mathbf{e}}(\mathbf{m m})$ \\
March & $\ldots \ldots$ & 41 & 20 & 20 \\
April $\ldots \ldots \ldots$ & 72 & 50 & 10 \\
May $\ldots \ldots \ldots \ldots$ & 100 & 80 & 58 \\
June $\ldots \ldots \ldots$ & 134 & 134 & 26 \\
July $\ldots \ldots \ldots$ & 113 & 40 & 40 \\
Total $\ldots \ldots \ldots$ & & 324 & 152 \\
\hline
\end{tabular}


Starting point of the use of stored moisture: April 1st.

A. Original profile

Stored moisture:

\begin{tabular}{|c|c|c|}
\hline Depth $(\mathrm{cm})$ & $\mathrm{pF}$ & Stored (mm) \\
\hline $0-10 \ldots$ & 2,17 & 14 \\
\hline $10-20$ & 2,14 & 14 \\
\hline $20-30$ & 2,11 & 15 \\
\hline Total & & 43 \\
\hline
\end{tabular}

Half the storage is exhausted on April 15th. Depth of the ground-water table at that moment is $140 \mathrm{~cm}$ below the root zone. Capillary supply during 90 days gives approximately $15 \mathrm{~mm}$. Total transpiration: $152+43+15=210 \mathrm{~mm}$.

B. Improved profile by means of deep ploughing to a depth of $50 \mathrm{~cm}$ Stored moisture:

\begin{tabular}{|c|c|c|c|}
\hline \multirow[t]{2}{*}{ Depth (cm) } & \multirow[t]{2}{*}{$\mathrm{pF}$} & \multicolumn{2}{|c|}{ Stored } \\
\hline & & clay & sand \\
\hline $0-10$ & 2,17 & 14 & 7 \\
\hline $10-20$ & 2,14 & 14 & 7 \\
\hline $20-30$ & 2,11 & 15 & 7 \\
\hline $30-40$ & 2,08 & 15 & 7 \\
\hline $40-50$ & 2,04 & 16 & 8 \\
\hline Total .... & & 74 & 36 \\
\hline
\end{tabular}

The ratio between clay and sand content is $3: 2$. So total stored moisture is $\frac{3 \times 74+2 \times 36}{5}=59 \mathrm{~mm}$. Half the storage is exhausted at aprroximately April 25th. Depth of the ground-water table at that moment is approximately $130 \mathrm{~cm}$ below the root zone. Capillary supply during 80 days gives approximately $18 \mathrm{~mm}$. Total transpiration: $230 \mathrm{~mm}$.

C. Improved profile by means of deep ploughing to a depth of $70 \mathrm{~cm}$

Here we find, in the way described above, a total transpiration of $250 \mathrm{~mm}$.

The following amounts of dry matter in straw and grains were harvested: A: 5750 ; B $6435 ; C: 6590 \mathrm{~kg} / \mathrm{ha}$. These amounts are to be increased with $2000 \mathrm{~kg} / \mathrm{ha}$ for stubble and roots (see TABLE 3 ).

TABle 3. Dry-matter weight of roots and stubble $(\mathrm{kg} / \mathrm{ha})$

\begin{tabular}{|c|c|}
\hline Winter wheat & 2500 \\
\hline Spring wheat & 2000 \\
\hline Spring barley & 2000 \\
\hline Oats $\ldots .$. & 2000 \\
\hline Beets .... & 500 \\
\hline Peas, beans . & 500 \\
\hline
\end{tabular}


When comparing $A$ and $B$ we find for $Q_{y}: \frac{8435}{7750}=1,09$ and for $Q_{m}: \frac{230}{210}=1,095$.

When comparing $A$ and $C$ we find $Q_{y}=1,11$ and $Q_{m}=1,19$.

For the not harvested roots and stubble, the amounts to be found in literature (BlOOdWORTH, 1958; KöhNLEIN 1954; KöneKamP, 1953; Lieshout, 1956) were used. In TABLE 4 the results of the field experiments are given.

\section{Discussion}

\subsection{Reliability of the single values}

If the theory described is right the value of $Q_{y}$ and $Q_{m}$ must be equal. This is not true for the single values. If we put them in a graph (FIG. 6) they scatter around a line that can be described with the equation $Q_{y}=1,30 Q_{m}-0,36$. As the variance is rather large $(\sigma=0,080)$, a significant difference between the given regression and the regression $Q_{y}=Q_{m}$ cannot be shown.

On the other hand the correlation between $Q_{y}$ and $Q_{m}$ is so high $(r=0,74)$ as to rule out any coincidence. Under conditions as given here, the correlation coefficient is already significantly different from zero at a $1 \%$ level above 0,51 .

Although the data obtained by the field experiments correlate well with the values of the theoretical calculations, the rather great variances in the single values make a further investigation into the reliability of the single factors necessary.

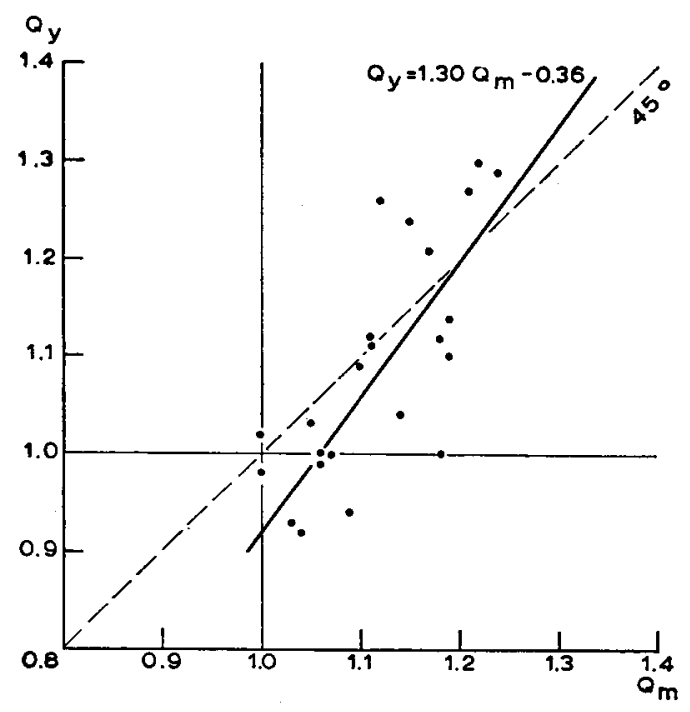

Fig. 6

The relation between the totaltranspiration ratio $\left(Q_{m}\right)$ and the total dry-matter/yield ratio $\left(Q_{y}\right)$

Errors in the measured yield. As can be seen in TABLE 4 most of the field-trial yields are means of those from four replicate plots. The standard error in yield of one single plot varies from $5 \%$ to $10 \%$. Increasing the number of replicates does not decrease this error or its spread. This means that there is a constant variance in productivity of about $7,5 \%$ of the mean yield on these soils. This value is in 


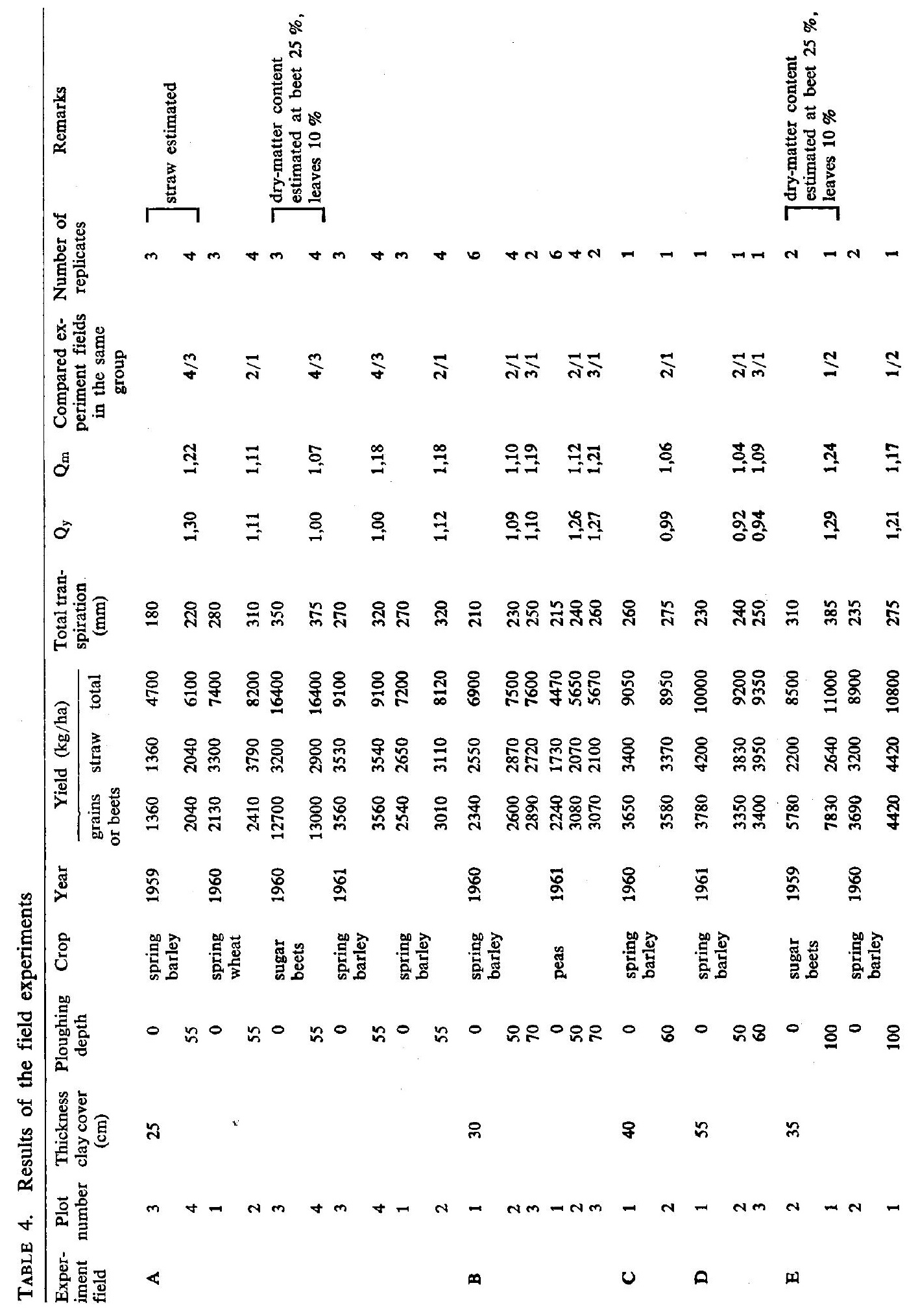


good accordance with such errors known to occur in other field trials. From these standard errors one may expect a standard error of approximately $5 \%$ in the $Q_{y}$-values.

Errors in the calculated evapotranspiration. In the method of calculating total evapotranspiration here used there are two instances where an assumption is made that has no direct theoretical foundation.

In the first place, has the starting point for calculating capillary rise been chosen at the moment that half the amount of direct available moisture was consumed. A mistake in this assumption means that the length of the period in which capillary flow occurs with flow velocities of less than half a millimeter a day, differs from the one we took. As the same criterion is used for both the ploughed and the unploughed sections of the fields, the error in the calculated amount of available water will be nearly the same for both sections. The largest time error is equal to the length of the period regarded as being necessary for consuming half the amount of direct available water. This means, that the error in $Q_{y}$ cannot exceed $3 \%$.

In the second place reduction-factors values used for transforming the evaporation according to Penman into crop transpiration are arbitrary. It is known that there are periods when this reduction factor has much higher values than 1,0 . In our case this can only influence the $Q_{m}$-values, if more water would be available than should be needed for the maximal evapotranspiration calculated with the reduction factors of TABLE 2. Since this has never been the case, a deviation of the reduction factors used has no influence on the value of $Q_{m}$.

In comparing the ratios $Q_{y}$ and $Q_{m}$ we expected $D=Q_{y}-Q_{m}=0$. With the standard errors found above, the standard error in $\mathrm{D}$ must be approximately $6 \%$. So, all $\mathrm{D}$ values of less than 0,12 are not significant at the $5 \%$-level. On the other hand all values of $Q_{m}$ less than 1,10 and of $Q_{y}$ less than 1,06 are not significantly different from 1,00 .

\subsection{The transpiration coefficient}

It has been shown, for our pot experiment, that a rectilinear relation exists between yield and evapotranspiration $(Y=c . E-b)$. From this it was concluded, that also in practice the transpiration coefficient $c$ is a constant for one field, one year and one crop on both improved and undisturbed profiles. In cases, however, where the subsoil has qualities that differ greatly from those of the topsoil, e.g. $\mathrm{pH}$ and salinity, it will have to be checked whether this assumption is still valid.

\subsection{Practical meaning of the measured yields}

In the relation between yield and available moisture as described above, yield was defined as total dry-matter production. In practice, however, one is not interested in total dry matter, but only in that of the marketable parts. With the aid of TABLE 3 and the total dry-matter yields given in TABLE 4, the marketable dry-matter ratio $Q_{y m}$ was calculated. $Q_{y m}$ is then the ratio of the dry-matter yield of marketable parts on the ploughed and the unploughed fields. Putting these $Q_{y m}$-values in a graph against $Q_{y}$-values (FIG. 7) shows, that the gain in marketable yield is at least proportional to the gain in total yield (FIG. 6). So using $Q_{y}$ for calculating the effect of the soil improvement, one will get a smaller effect than will be obtained in reality in marketable parts. 


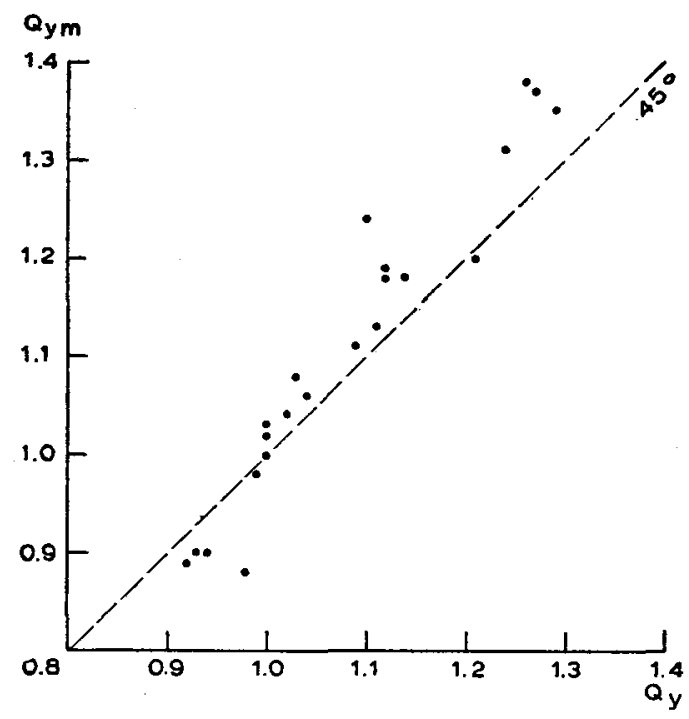

FIG. 7

The relation between the total dry matter/yield ratio $\left(Q_{y}\right)$ and the marketable dry matter/yield ratio $\left(Q^{y m}\right)$

\section{Conclusions}

It is possible to predict the effect on the yield of the improvement of clay cover soils, by calculating the gain in total available water.

To be sure of a positive effect of a possible improvement, the calculated increase of available moisture must be more than $10 \%$ of the original amount of moisture available.

\section{I T E R A T U R E}

BLOODWORTH, M. E. A. O. 1958 Root distribution of some irrigated crops using undisturbed

KöHNLEIN, J. soil cores. Agron. J. 50, 6:317-320.

1955 Die Ernte- und Wurzelrückstände und ihre Bedeutung für Vorfruchtwirkung und Bodenfruchtbarkeit. De plantenwortel in de landbouw. 178-191. Staatsdrukkerij, Den Haag.

KöNEKAMP, A. H.

1953 Teilergebnisse von Wurzeluntrsuchungen. Zeitschr. f. Pfl.ernähr., Düngung, Bodenk. 60, 2: 113-125.

LIESHOUT, J. W. vaN

1956 De beworteling van een aantal landbouwgewassen. Versl. Landb. Onderz. No. 62.16.

SCHUURMAN, J. J.

1955 De wortelontwikkeling van wintertarwe in klei-zandprofielen in betonnen buizen bij ongelijke kleilaagdikte, grondwaterstand en fijnheidsgraad van het zand. Versl. Landb. Onderz. No. $61.7,122-135$.

WIND, G. P., and

1961 The soil-physical basis of the improvement of clay cover-

A. P. HIDDING soils. Neth. J. agric. Sci. 9, 4: 281-292 and Techn. Bull. I.C.W. No. 25. 